Łukasz Kołtuniak

Uniwersytet Jagielloński

DOI: $10.19195 / 2450-274 X .3 .7$

\title{
Szanse na jedność Grupy Wyszehradzkiej w kontekście polityki krajów V4 wobec Rosji i Chin oraz kryzysu ukraińskiego
}

Abstrakt: Po 2004 r. wydawało się, że wobec osiągnięcia wspólnego celu, jakim była integracja z UE i NATO, formuła Grupy Wyszehradzkiej ulega stopniowemu wyczerpaniu. Wspólny i bezkompromisowy (jakkolwiek by nie oceniać jego moralnej słuszności) sprzeciw wobec tzw. kwot na migrantów stwarza dziś wrażenie istnienia wspólnej platformy interesów krajów V4. Czy jednak platforma ta jest stała i Wyszehrad może integrować się również wobec idei „pozytywnych”. Problem jedności krajów regionu rozważę w niniejszym tekście w kontekście ich postawy w czasie kryzysu ukraińskiego, a także polityki wobec Rosji i Chin. Kryzys ukraiński w 2014 r. stwarzał bowiem zdaniem wielu ekspertów ryzyko rozpadu Grupy Wyszehradzkiej. Było to wynikiem braku wsparcia dla Ukrainy zwłaszcza ze strony Czech i Węgier przy tradycyjnie prometejskim stanowisku ówczesnego polskiego rządu. Czy od 2014 r. udało się odbudować wspólną agendę? Czy Rosja może skutecznie stosować w regionie zasadę divide et impera? Na te pytania będę chciał odpowiedzieć, analizując politykę krajów regionu wobec kryzysu z uwzględnieniem całego kontekstu polityki analizowanych państw.

Stowa kluczowe: Wyszehrad, Rosja, Chiny, Ukraina, populizm, soft powe

\section{Chances for the unity of the Visegrad Group in the context of V4 countries policy towards Russia and China and the Ukrainian crisis}

Abstract: After 2004, in the whole V4 region it was the conviction that Visegrad formula is exhausted. However, this situation began changed after common strong opposition against migrant quota. But is the common "positive" idea exist? The problem of regional unity will be analysed in the context of policy towards Russia, China and Ukrainian crisis. During Ukrainian crisis in 2014 it might seem that the Visegrad project may finally collapsed. Poland traditionally strongly supported Ukraine but Czech Republic and Hungary tried to avoid the clear statements. The question is if today, 3 years after Russian aggression, Visegrad states have more of common interests? And does Russia 
have the instruments to successfully divide our region? Each state's policy will be analysed separately in the context of general ideas in foreign policy and attitude to Ukrainian crisis.

Keywords: Visegrad, Ukraine, Russia, China, populism, soft power

Kryzys ukraiński ujawnił zasadność podnoszonych w nauce opinii, jakoby wspólnota interesów Grupy Wyszehradzkiej (V4) skończyła się wraz z przystąpieniem tworzących ją państw do Unii Europejskiej. Teoretycznie wszystkie kraje V4 zaznały w przeszłości rządów komunistycznych. Wydawałoby się zatem, iż powinna je łączyć pewna, może nawet przesadna, wrażliwość na zagrożenia płynące ze Wschodu. Jednak gdy wybuchł kryzys, żaden z tych krajów, oprócz Polski, nie zajął jednoznacznego stanowiska. Co więcej, jak zostanie udowodnione w dalszej części pracy, Czechy i Węgry nie zrezygnowały z formułowania nowej agendy, w której Rosja jest raczej partnerem biznesowym, a nie źródłem potencjalnego zagrożenia.

Celem niniejszego artykułu jest ukazanie złożoności stanowisk Czech, Słowacji i Węgier wobec interesującego nas konfliktu. Stosunek każdego z tych państw do Rosji oraz sytuacji na Ukrainie zostanie rozpatrzona osobno. Każde omówienie będzie zawierać analizę polityki wobec Moskwy i Kijowa przy uwzględnieniu całości polityki zagranicznej tych krajów. Na początku przedstawimy uwarunkowanie polityczne w wymienionych państwach w latach 2014-2017. Niekiedy będzie to dłuższa cezura czasowa. Następnie pokażemy główne idee polityki zagranicznej, jakimi kierują się tamtejsze rządy. Rozważymy także kontekst rosnących wpływów chińskich w regionie. Konkluzje artykułu będą także zawierać pytanie o wspólnotę interesów państw V4.

Wiemy, że w 2004 r. została zwieńczona sukcesem wspólna agenda państw regionu, jakim był „powrót do Europy”. Po tym sukcesie, zdaniem niemal wszystkich analityków, nie udało się sformułować nowej wspólnej agendy krajów Wyszehradu. Kryzys ukraiński zdawał się dowodzić, że inicjatywa ta jest de facto martwa. W Polsce pojawił się pomysł szerszej współpracy regionalnej, czyli tzw. Trójmorza, który był wcielany w życie już przez rządy Platformy Obywatelskiej. W kręgach polskiej prawicy zatem pojawiła się również idea swego rodzaju Unii Środkowoeuropejskiej, czyli Międzymorza. Mimo że Międzymorze także było projektem integracji regionu Europy Środkowej, u źródeł tej idei leżało przekonanie, że Wyszehrad wyczerpał już swoje możliwości i konieczny będzie szerszy projekt regionalny. Tymczasem nieoczekiwanie 2015 r. przyniósł renesans Grupy Wyszehradzkiej. W czasie kryzysu imigracyjnego rządy wszystkich tych państw, w tym Polski, opowiedziały się przeciwko pomysłowi relokacji uchodźców, czyli tzw. kwotom. W tym momencie pozornie wydaje się, że Wyszehrad jest silniejszy niż kiedykolwiek. Z jednej strony, gdy rząd Ewy Kopacz, który koniec końców ustąpił w sprawie kwot, został zastąpiony przez gabinet Beaty Szydło, państwa Grupy mówią w polityce unijnej już niemal jednym głosem. Z drugiej - ciągle nasuwa się pytanie: czy wspólnota interesów okaże się trwała? Dla unijnych elit V4 jest w tym momencie symbolem „zła” hamującego europejską jedność. Na- 
wet jeśli obarczanie Europy Środkowej odpowiedzialnością za strukturalną słabość współczesnej UE wydaje się mocno na wyrost, to jednak pojawia się pytanie: jaką inną płaszczyznę integracji (aniżeli sprawa kwot) zbuduje Wyszehrad? Na koniec artykułu rozważymy, czy taka wspólna platforma wystarczy, aby przykryć coraz wyraźniejszą różnicę interesów.

\section{Czechy}

W 2013 r. do władzy w Czechach doszła koalicja socjaldemokratów, chadeków i populistycznej partii ANO. Premierem został socjaldemokrata Bohuslav Sobotka. Koalicja ta rządziła zatem od początku kryzysu ukraińskiego.

Czechy mają tradycję idealistycznej polityki w duchu demokracji i praw człowieka. Gorącym orędownikiem takiej linii był były prezydent Vaclav Havel ${ }^{1}$. Mimo że w latach 1989-2013 kurs ten był osłabiany przez zwolennika paradygmatu realistycznego, Vaclava Klausa, Czechy, które wspierały dysydentów, takich jak np. Aung San Suu Kyi czy Dalajlama, zyskały duży prestiż jako kraj angażujący się w walkę o prawa człowieka.

Zarówno rząd trójkoalicji, jak i prezydent Miloš Zeman podważyli dotychczasową linię w polityce zagranicznej. Zeman dał się poznać jako zwolennik końca amerykańskiej dominacji oraz otwarcia na Rosję i Chiny. Prezydent zdecydowanie odmówił wsparcia Ukrainy w kryzysie; co więcej, wiele jego wypowiedzi może być interpretowanych jako poparcie dla Rosji ${ }^{2}$. Jednocześnie propaguje ideę „Nowego Jedwabnego Szlaku" i lobbuje za otwarciem Czech na biznes z Chin. Zeman, który wybory wygrał dzięki hasłu uczynienia z Czech „drugiej Szwecji”, obecnie zdaje się angażować w coś na kształt „wspólnoty nieliberalnych demokratów”3. Przy każdej okazji krytykuje UE i NATO4 ${ }^{4}$. Jednocześnie z wielkimi nadziejami przyjął zwycięstwo wyborcze Donalda Trumpa ${ }^{5}$. Prezydent pozostaje oczywiście w ostrej opozycji do tzw. havlowskiej inteligencji.

Rząd Sobotki oficjalnie deklarował wsparcie dla integralności terytorialnej Ukrainy oraz ukraińskich reform. Jednak część czeskiej opinii publicznej była roz-

${ }^{1}$ Havel uważał, że Czechy mają szczególny obowiązek troski o prawa człowieka, wynikający z ich własnych doświadczeń dwóch totalitaryzmów.

2 W czasie prac nad tym artykułem świat obiegła wypowiedź Zemana o możliwości „sprzedaży” Krymu przez Ukrainę. Czescy komentatorzy zalecali dyplomatom zdecydowane odcięcie się od słów i działań prezydenta.

3 Zeman zdecydowanie atakuje rzekomy „neokonserwatyzm”, na jakim jego zdaniem opiera się UE.

4 Por. np. Zeman vztach $k$ Rusko je ambivalentni. NATO ho kritizuje i bere za partnera, https:// www.lidovky.cz/zeman-vztah-k-rusku-je-ambivalentni-nato-ho-kritizuje-i-bere-za-partnera-1au-/ zpravy-domov.aspx?c=A160709_190434_ln_domov_ele (dostęp: 15 października 2017).

5 Prezydent wielokrotnie chwalił styl polityczny Donalda Trumpa. Na razie (3 czerwca 2018) nie doszło jednak do spotkania polityków. 
czarowana wyraźną ambiwalencją postawy gabinetu. Najbardziej zdecydowane stanowisko wobec rosyjskich działań zajął minister spraw zagranicznych Lubomir Zaoralek.

Kryzys ukraiński wywołał ogólnonarodową dyskusję na temat przyszłości czeskiej polityki zagranicznej - 75\% Czechów w sondażach deklarowało niechęć lub wstrzemięźliwość wobec putinowskiej Rosji ${ }^{6}$. Trzeba jednak pamiętać, że Czesi w przeszłości postrzegali to mocarstwo nie jako zagrożenie, a sojusznika. W okresie narodowego odrodzenia w XIX w. żywy był ruch zapoczątkowany przez Karela Havliczka, postrzegający Rosję jako „wyzwolicielkę Słowian”7. W czasie kryzysu sudeckiego w 1938 r. jedynie ZSRR zaproponował pomoc militarną dla Czechosłowacji. Dopiero inwazja Układu Warszawskiego w 1968 r. zmieniła dość znacząco percepcję Rosji wśród czeskich elit. Podczas kryzysu ujawnił się silny nurt opowiadający się wręcz za wsparciem rosyjskich aspiracji podważenia unilateralnego ładu międzynarodowego.

Najpoważniejszą próbą intelektualnego uzasadnienia takich koncepcji był głośny tekst Petra Drulaka - sekretarza stanu w ministerstwie spraw zagranicznych oraz byłego dyrektora znanego praskiego think tanku UMV, w którym zaproponował redefinicję czeskiej polityki zagranicznej. Artykuł był ostrą negacją tzw. paradygmatu havlowskiego. Autor zarzucił byłemu prezydentowi pozorną walkę o prawa człowieka, która tak naprawdę była realizacją doktryny neokonserwatywnej. Drulak sugerował, że polityka Havla de facto oznaczała realizację interesów USA w globalnej polityce. Jak bowiem pogodzić - pytał analityk - z jednej strony podkreślanie prymatu idei praw człowieka i walkę o te prawa np. na Kubie, z drugiej wsparcie dla Izraela czy Arabii Saudyjskiej? Ideologia neokonserwatywna oznaczała prymat idei praw politycznych nad socjalnymi i kulturowymi ${ }^{8}$, tymczasem według Drulaka Czechy mogą się pochwalić długą tradycją rozumienia praw człowieka w szerszym kontekście. Jednak autorytetem przy takim pojmowaniu idei praw człowieka może być nie Havel, a pierwszy czechosłowacki prezydent Tomáš Garrigue Masaryk. Analityk widzi zgodność między ideami Masaryka a współczesnym rozumieniem praw człowieka ${ }^{9}$. Wielkie nierówności, jakie powoduje globalizacja, oznaczają bowiem, że praw człowieka nie można już postrzegać tylko w wymiarze politycznym, ponieważ pominięcie wymiaru ekonomicznego i kulturowego prowadzi do rażącego wzrostu nierówności i niesprawiedliwości. Na koniec Drulak stawia najbardziej kontrowersyjną tezę — mianowicie sugeruje, iż

${ }^{6}$ Pruzkum: Cesi duveruji najvice papezovi a Zemanovi. Merkelova se propada, https://www.lidovky.cz/pruzkum-cesi-duveruji-nejvice-papezovi-a-zemanovi-merkelova-se-propada-1af-/zpravy -domov.aspx?c=A160127_170913_ln_domov_ELE (dostęp: 15 października 2017).

7 Dość długo takie słowianofilskie postrzeganie Rosji było w Czechach dominujące.

8 P. Drulak, Lidska prava $v$ zahranicni politice anem sneni $k$ naivite. A zpet?, http://denikreferendum.cz/clanek/17205-lidska-prava-v-zahranicni-politice-aneb-od-sneni-k-naivite-a-zpet (dostęp: 20 września 2017).

9 Ibidem. 
kluczowe dziś dla rozumienia praw człowieka idee praw ekonomicznych i kulturowych mogą być lepiej respektowane np. w Rosji czy Chinach niż w USA ${ }^{10}$.

Teza ta wyjaśnia, dlaczego tekst, który został wręcz nazwany „doktryną Drulaka”, wywołał takie kontrowersje. Liberalni analitycy byli bowiem zgodni - tu nie chodzi o prawa człowieka. Celem artykułu było niezwykle finezyjne uzasadnienie politycznego zwrotu w kierunku Rosji i Chin ${ }^{11}$. Był to bowiem okres, w którym liberałowie podejrzewali, że rząd przedkłada korzyści z wymiany handlowej z tymi mocarstwami ponad moralne kontrowersje, jakie budzi polityka Moskwy czy Pekinu.

Faktem jest, że właśnie w czasie, gdy powstał artykuł Drulaka, wydawało się, że paradygmat havlowski jest zastępowany przez realizm czy - zdaniem krytyków - pozorny realizm, tym bardziej że spośród partii politycznych właściwie tylko liberalna TOP 9 oraz chadecka KDU-ČSL w pełni opowiadają się za idealistycznym paradygmatem $\mathrm{w}$ polityce zagranicznej. Idealizm jest jednak ciągle gorąco popierany przez opiniotwórcze media, takie jak „Respect”, „Echo 24”, „Hospodářské Noviny” czy półrocznik idei „Střední Evropa Revue”. Dlatego po ukazaniu się artykułu Drulaka presja mediów oraz środowisk inteligenckich była tak silna, że minister Zaoralek oficjalnie stwierdził, iż nie ma odwrotu od havlizmu i odwołał Drulaka ze stanowiska.

Tym niemniej Czechy unikają jednoznacznego poparcia dla Ukrainy. Wartość rosyjskich inwestycji jest tak duża ${ }^{12}$, że rząd w Pradze znalazł się między przysłowiowym młotem a kowadłem. To samo dotyczy inwestycji chińskich. Politycy CSSD oraz prezydent Zeman są wręcz zafascynowani korzyściami, jakie oferuje Pekin. Gdy jesienią 2016 r. jeden z ministrów KDU-ČSL, Daniel Herman, spotkał się w Pradze z Dalajlamą, politycy lewicy wpadli w panikę. Pod listem z przeprosinami do władz Chin podpisali się wszyscy ministrowie z ramienia CSSD oraz prezydent Zeman ${ }^{13}$. Trzeba pamiętać, że choć CSSD formalnie wywodzi się z opozycji demokratycznej, partia ta przeszła znaczną ewolucję. Jej założycielem był legendarny dysydent Jiř́ Dienstibier i początkowo formacja ta odwoływała się do dysydenckiego idealizmu, także w polityce zagranicznej. W okresie przywództwa Miloša Zemana CSSD stała się jednak partią właściwie oligarchiczną, postrzegającą politykę raczej w kategoriach gry interesów i doraźnych korzyści gospodar-

10 P. Drulak, Tri rozmery ceske debaty o zahranicni politice lidskych prav, [w:] Lidská práva: (ne) smysl české politiky?, red. J. Přibáň, V. Bělohradský, Praha 2015, s. 51-52.

11 Drulak konci na zahranici. Nepohodl se s ministrem, https://www.novinky.cz/domaci/408644drulak-konci-na-zahranici-nepohodl-se-s-ministrem.html (dostęp: 15 października 2017).

12 Pod koniec 2015 r. wartość inwestycji rosyjskich w Czechach wynosiła ok. 20 mld koron (w przybliżeniu 3 mld złotych) - D. Tramba, Ruske investice v Cesku rosnou. Mnohe ale krahuji, http:// www.dotyk.cz/publicistika/ruske-investice-v-cesku-rostou-mnohe-ale-krachuji-20160811.html (dostęp: 15 października 2017).

13 Ctyri najvyssi politici se distancovali od schuzki Hermana $z$ Dalajlamou, http://zpravy.idnes.cz/ctyri-nejvyssi-politici-se-distancovali-od-schuzky-hermana-s-dalajlamou-14q-/domaci. aspx?c=A161018_160816_domaci_kop (dostęp: 13 października 2017). 
czych. O ile Sobotka i Zaoralek są bliscy nurtowi idealistycznemu w partii, o tyle coraz silniejsze zdają się wpływy polityków bliskich prezydentowi ${ }^{14}$.

Wszystko wskazuje na to, że po wyborach najsilniejszą formacją nowego rządu będzie populistyczna Partia ANO miliardera Andreja Babisza. ANO to formacja amorficzna, która poza hasłami „zarządzania państwem tak, jak firmą” czy „ukarania złodziei" nie przedstawiła na razie spójnej strategii swej polityki - zarówno wewnętrznej, jak i międzynarodowej. Liberałowie obawiają się wręcz, że po wyborach ANO może skierować Czechy w stronę zaostrzenia sytuacji wewnętrznej i naruszeń praworządności ${ }^{15}$. Memento ma tu być przykład Polski i Węgier. Wydaje się jednak, że każdy kolejny czeski rząd skazany będzie na balans w polityce zagranicznej między dwoma omówionymi paradygmatami ze względu na silną polaryzację czeskiej opinii publicznej wokół miejsca tego państwa w globalnej polityce. Czesi nieufnie patrzą na Zachód, choć z pewnością znaczna część opinii publicznej nie wyklucza sojuszy, które mogłyby wzmocnić kraj w geopolitycznej konfrontacji z Rosją. Jednak, mimo że większość Czechów nie darzy przesadną sympatią ani Chin, ani Rosji, dominuje przekonanie o konieczności utrzymania korzyści, jakie daje wymiana handlowa z tymi mocarstwami. Jednocześnie stopień powiązania czeskiej i niemieckiej gospodarki jest tak duży, że przy wszystkich zastrzeżeniach względem polityki Angeli Merkel Czesi, może poza komunistyczną KSCM (Komunistyczna Partia Czech i Moraw), nie wyobrażają sobie pogorszenia stosunków z Niemcami.

Jeżeli chodzi o stosunki z Chinami w okresie prezydentury Vaclava Havla, obóz prezydencki bardzo pryncypialnie podnosił kwestię praw człowieka. Sam Havel regularnie spotykał się z Dalajlamą. Oficjalnie stosunki czesko-chińskie były zatem zamrożone. Jednak kolejni premierzy Czech zajmowali mniej twarde stanowisko wobec łamania przez Pekin praw człowieka. Dlatego, jak twierdzą czescy analitycy, chińscy decydenci nauczyli się „prowadzić interesy z Czechami z pominięciem ośrodka prezydenckiego" ${ }^{\prime 6}$. Od momentu szczytu $16+1$ i przedstawienia chińskiej oferty dla Europy Środkowej Czechy walczą o rolę regionalnego lidera w kontaktach z Pekinem. Wywołuje to silny opór zwolenników „polityki wartości”. Dlatego pojawiają się pomysły, aby o prawach człowieka rozmawiać z Chinami nie w relacjach bilateralnych, ale wykorzystując instytucje Unii Europejskiej ${ }^{17}$. Jednocześnie Praga stosunkowo najlepiej korzysta z chińskich inwestycji. Co cieka-

14 Zeman stratil svym chovanim v CSSD behem vladni krize vliv, rika sef Sobotkovych poradcu Spidla, https://archiv.ihned.cz/c1-65741920-zeman-ztratil-svym-chovanim-behem-vladni-krize-v-cssd-vliv -rika-sef-sobotkovych-poradcu-spidla (dostęp: 10 października 2017).

15 To by bylo, aby se na vás něco nenašlo, rozmowa Petra Holuba z Miroslavem Kalouskiem, „Týdeník Echo" 12.10.2017, nr 41, https://echo24.cz/a/p7cWA/to-by-bylo-aby-se-na-vas-neco-nenaslo (dostęp: 20 października 2017). ANO dość niechętnie odnosi się do typowych dla liberalnej demokracji ograniczeń władzy większości. Babisz twierdzi, że państwem należy rządzić „tak jak firmą”.

16 R. Furst, Cesko-cinske vztachy, od bezradnosti k aktivni politce, UMV policy papers, http://www. iir.cz/en/article/cesko-cinske-vztahy-od-bezradnosti-k-aktivni-politice (dostęp: 20 października 2017).

17 Ibidem. 
we, ze wszystkich tych przedsięwzięć największym echem odbiło się wykupienie przez chińskich inwestorów klubu piłkarskiego Slavia Praga ${ }^{18}$. Ta inwestycja, która z różnych powodów - wykraczających poza ramy tego artykułu - wzbudzała negatywne reakcje w kręgach kibiców piłkarskich, w jakimś stopniu negatywnie wpływa na percepcję całego chińskiego biznesu wśród tzw. zwykłych Czechów ${ }^{19}$.

\section{Słowacja}

Słowacki premier Robert Fico, oskarżany często o populizm, zdefiniował pozycję swojego kraju jako członka tzw. twardego jądra UE. Sam Fico bardzo bezpardonowo występował przeciwko kwotom. Jednocześnie jednak rząd wysyłał zachodnim partnerom sygnały świadczące o tym, że różnice w sprawie migracji nie mogą rzutować na ich wzajemne stosunki ${ }^{20}$. Zachowując opinię „wyszehradzkiego prymusa", czyli kraju, z którym obecnie Brukseli współpracuje się najlepiej, nie można powiedzieć, jakoby rząd Fico poświęcał w relacjach z Brukselą tzw. interes narodowy. Przykładem jest wsparcie stanowiska Polski w sprawie gazociągu North Stream.

Za przejaw walki o interes narodowy Fico uznaje także postulat sankcji wobec Rosji. Równocześnie stanowisko władz w Bratysławie dalekie jest od bezkrytycyzmu wobec Rosji, jaki reprezentuje Miloš Zeman. Cała polityka Słowacji w czasie kryzysu ukraińskiego oparta była na próbie realnego wsparcia ukraińskiej transformacji przy zachowaniu dobrych relacji z Rosją. Istnieją silne więzi łączące gospodarki obu państw. Fico to polityk, który długo był postrzegany przez swych przeciwników jako postkomunistyczny „aparatczyk”, a w czasie swojej pierwszej kadencji (2006-2010) rząd złożony z jego partii SMER oraz nacjonalistów SNS oskarżany był (także na arenie międzynarodowej) o nadużycia władzy ${ }^{21}$. Premier wierzy we współpracę Zachodu i Rosji i jest bardzo powściągliwy wobec USA. Jednak w czasie Euromajdanu stosunek Słowacji do Ukrainy zmienił się i obecnie Bratysława zdecydowanie popiera europejskie aspiracje Ukrainy. Stara się również okazać Kijowowi realną pomoc w procesach transformacyjnych. Fico okazywał jednak brak zaufania pomarańczowym władzom Ukrainy po kryzysie gazowym 2009 r., w wypadku którego jego zdaniem polityka Kijowa zagrażała słowackim

18 Od 2015 r. sponsorem Slavii jest CEFC China Energy Group Company.

19 Spora część czeskich kibiców uważa, że doszło do naruszenia futbolowych reguł uczciwej konkurencji. Slavia jest niekiedy pogardliwie określana jako „China” i pojawiają się głosy przeciwne chińskim inwestycjom, które w opinii kibiców mają być równie nietransparentne, jak w ich odczuciu inwestycja CEFC w Slavię.

20 Slovensko se stava poslusnym clenem EU. Fico se pry ohledne bezencu s Junckerem placl, http:// www.parlamentnilisty.cz/arena/monitor/Slovensko-se-stava-poslusnym-clenem-EU-Fico-si-pry -ohledne-bezencu-s-Junckerem-placl-498119 (dostęp: 14 października 2017).

21 P. Bajda, Elity polityczne na Słowacji w latach 1989-2010. Kręta droga do nowoczesnego państwa, Warszawa 2010, s. 250-300. 
interesom $^{22}$. Obecnie te stosunki układają się dużo bardziej poprawnie. Jak już wspomniano, Słowacja opowiada się także za zniesieniem sankcji wobec Rosji. Zdaniem rządu sankcje te nie są skuteczne i jedynie utwardzają stanowisko Moskwy. Słowacja przekonuje, że cały konflikt można rozwiązać tylko w oparciu o porozumienia z Mińska.

Widzimy więc, że Bratysława jest uwikłana w swoisty „konflikt lojalności”. Dwóch ważnych dla niej partnerów znajduje się w sytuacji, w której dobre relacje $\mathrm{z}$ jednym $\mathrm{z}$ nich mogą rzutować na relacje $\mathrm{z}$ drugim. Wydaje się, że od 2014 r. Fico wybiera raczej dobre relacje $z$ Ukrainą ${ }^{23}$. Warto też pamiętać o dążeniu słowackiego rządu do utrzymania miejsca $\mathrm{w}$ „twardym jądrze UE”. Samodzielnie przeprowadzony reset w relacjach z Rosją mógłby bowiem rzutować na całość relacji z Brukselą.

Na Słowacji, podobnie jak w Czechach, istnieją dwa ośrodki władzy. Prezydent Andrej Kiska zdecydowanie stawia na jedność świata euroatlantyckiego i otwarcie krytykuje politykę Rosji ${ }^{24}$. Wydaje się jednak, że mimo trwającego ostrego sporu obu obozów władzy na arenie wewnętrznej w polityce zagranicznej różnice te nie są aż tak znaczące.

Słowacja stała się wręcz swego rodzaju „prymusem w regionie”. Przyjęcie ograniczonej liczby uchodźców radykalnie zwiększyło prestiż tego kraju w UE. W słowackich mediach pojawiają się zatem zachęty do „odcięcia się" od reszty krajów Wyszehradu ${ }^{25}$. Rząd Roberta Fico faktycznie prowadzi pewną grę mającą pokazać, że to Słowacja jest najbardziej przewidywalnym i proeuropejskim państwem regionu. Stawką tej gry są oczywiście także europejskie inwestycje.

Jednocześnie Słowacja zdradza aspiracje do odgrywania roli „chińskiego okna na Europę Środkową". Na płaszczyźnie politycznej relacje obu państw układają się poprawnie. Słowacja, na co zwracają uwagę tamtejsi analitycy, przyciąga jednak najmniej chińskich inwestorów spośród krajów V4 ${ }^{26}$. Dlatego celem polityki zagranicznej jest tu przełożenie dobrych relacji politycznych na konkretne chińskie inwestycje. Ważną dla Bratysławy płaszczyzną jest przyciągnięcie chińskich turystów ${ }^{27}$. Niestety przez ostatni rok (2016-2017) wystąpił poważny regres w rela-

22 J. Groszkowski, T. Iwański, A. Sadecki, Raport OSW: Sasiad odkrywany na nowo. Stosunki Czech, Stowacji i Weggier z Ukraina, https://www.osw.waw.pl/pl/publikacje/raport-osw/2017-08-03/ sasiad-odkrywany-na-nowo-stosunki-czech-slowacji-i-wegier-z-ukraina (dostęp: 20 września 2017).

23 Ibidem.

24 R. Cuprik, Fico, potrebujem aby se Kiska koncentroval, https://domov.sme.sk/c/20672305/fico -z-odmeny-pre-bzana-by-sme-sa-mali-poucit.html?ref=njctse (dostęp: 13 października 2017).

25 L. Ondercanin, Vasaryova, ked sa Polsko a Madarsko dohaduji bez nas musime byt opatrni, https://www.sme.sk/diskusie/3182096/4/Vasaryova-Ked-sa-Polsko-a-Madarsko-dohaduju-bez-nasmusime-byt-opatrni.html (dostęp: 15 października 2017).

26 Zdaniem słowackich analityków chińskie inwestycje na Słowacji są prawie niezauważalne; por. np. T. Nejedly, Cins sype do Evropy miliardy Slovensko nevidi, https://www.etrend.sk/trend-archiv/rok-2015/cislo-39/cinske-miliardy-obchadzaju-slovensko.html (dostęp: 5 grudnia 2017).

27 Co może cinskych turistu prilakat na Slovensko? Cisty vzduch a nakupy?, https://cestovanie. pravda.sk/cestovny-ruch/clanok/353318-co-moze-cinskych-turistov-prilakat-na-slovensko-cistyvzduch-aj-nakupy/ (dostęp: 5 grudnia 2017). 
cjach słowacko-chińskich. Miało to związek ze spotkaniem między prezydentem Andrejem Kiską a Dalajlamą. Podobnie jak w wypadku analogicznego spotkania z czeskim ministrem Hermanem, chińscy przywódcy bezwzględnie egzekwują przestrzeganie zasady ,jednych Chin" ${ }^{28}$. Tymczasem wymiar praw człowieka staje się coraz ważniejszy nie tylko w polityce prezydenta Kiski, lecz także rządu Fico ${ }^{29}$. Powstaje zatem pytanie, czy w przyszłości sprawy te nie będą rzutować na relacje bilateralne. Obecnie także Słowacja wydaje się jednak zafascynowana korzyściami gospodarczymi, przede wszystkim wizją „Nowego Jedwabnego Szlaku”.

\section{Węgry}

Wiktor Orban realizuje na Węgrzech kontrowersyjną politykę przebudowy systemu polityczno-społecznego ${ }^{30}$. Jednym z wyznaczników nowego modelu państwa ma być samodzielna polityka zagraniczna. Należy jednak pamiętać, że Orban unika działań, które mogłyby zostać zrozumiane jako podważanie jedności UE. Mimo że Komisja Europejska wielokrotnie straszyła Węgry sankcjami, zawsze udawało się znaleźć rozwiązanie. Premier wysyła także przyjazne sygnały do Niemiec, podkreślając pozytywne znaczenie roli, jaką odgrywają w Europie.

Jednocześnie Orban przebudowuje Węgry w kierunku modelu radykalnie odrzucanego przez europejskie elity. W 2014 r. w swym słynnym wystąpieniu w Baile Tusnad węgierski premier mówił o „nieliberalnej demokracji” jako alternatywnym modelu rozwoju dla jego kraju. Wystąpienie,w którym lider partii Fidesz mówił o wyczerpaniu modelu liberalnego, spotkało się z bardzo negatywną reakcją zarówno w Europie, jak i w USA. Jako przykładowe nieliberalne demokracje, kraje, które osiągnęły sukces, negując zachodni model, Orban wskazał Turcję, Singapur, Chiny i Rosję ${ }^{31}$.

Na dłuższą metę premier Węgier zdaje się zmierzać do budowy ładu, w którym kryterium przestrzegania standardów liberalno-demokratycznych nie będzie już wyznacznikiem rangi danego kraju w stosunkach międzynarodowych. Gdy Donald Trump wygrał wybory prezydenckie w USA, Orban powiedział „nareszcie koniec liberalnej nie demokracji, teraz my — prawdziwi demokraci — zbudujemy lepszy świat"32. Jednocześnie zarówno premier, jak i jego minister spraw zagra-

28 Reakcja chińskich dysydentów była niezwykle twarda - Chiny ograniczyły inwestycje na Słowacji, a także spotkania ze słowackimi decydentami. Rząd Roberta Fico starał się zająć postawę pojednawczą i nie dążył do zaostrzenia sporu.

29 Fico se ma na sumitu $v$ Rize ptat i na lidska prava $v$ Cine, https://www.denik.cz/ze_sveta/fico-sema-na-summitu-v-rize-ptat-i-na-lidska-prava-v-cine-20161103.html (dostęp: 5 grudnia 2017).

30 V. Orban, Baile Tusnad speech, https://budapestbeacon.com/full-text-of-viktor-orbans-speechat-baile-tusnad-tusnadfurdo-of-26-july-2014/ (dostęp: 15 września 2016).

31 Ibidem.

32 V. Orban o wyborach w USA. To koniec epoki liberalnej niedemokracji, https://wpolityce.pl/ polityka/314950-viktor-orban-jednoznacznie-o-wyborach-w-usa-to-koniec-epoki-liberalnej-niedemokracji (dostęp: 23 grudnia 2016). 
nicznych, Peter Szijarto, optują za powrotem do realizmu politycznego w relacjach międzynarodowych. Realizm ten miałby polegać na tym, że „moralna słuszność sprawy" nie będzie już miała prymatu przy ocenie konfliktu międzynarodowego nad interesem narodowym. W czasie kryzysu ukraińskiego doszło do wielu spotkań Orbana z Władimirem Putinem ${ }^{33}$. Wydaje się, że dla węgierskiego premiera kryzys był szansą na zademonstrowanie gotowości kraju do odgrywania aktywnej roli przy redefinicji globalnej polityki. Krytycy tej polityki pytają, czy naprawdę $\mathrm{w}$ interesie małych Węgier leży podważanie obowiązującego liberalno-demokratycznego ładu.

Nie należy sprowadzać polityki Orbana w kryzysie ukraińskim wyłącznie do koncepcji filozoficzno-politycznych. Za utrzymaniem dobrych relacji z Rosją stały także twarde interesy gospodarcze. Podobnie jak czeska i słowacka, także węgierska gospodarka jest coraz mocniej związana z rosyjską, czego dobrym przykładem może być budowa elektrowni w Paks ${ }^{34}$.

Węgry poszukują również chińskich inwestycji. Linia kolejowa Budapeszt-Belgrad, której budowę obiecali chińscy inwestorzy, to dobry przykład chińskiego zaangażowania w regionie. Minister Szijarto próbuje otworzyć Węgry na współpracę z takimi krajami, jak np. Azerbejdżan, Iran czy państwa Zatoki Perskiej ${ }^{35}$. Jednocześnie jednym z założeń dyplomacji Szijarto jest budowa pozycji Węgier w skali globalnej, a nie tylko wewnątrz UE.

Stosunek obecnych władz Węgier do Ukrainy jest zarazem najbardziej problematyczny spośród wszystkich państw V4. W 2015 r. Węgry podniosły wobec Ukrainy roszczenia dotyczące sytuacji swojej mniejszości na Zakarpaciu ${ }^{36}$. Zgłaszanie roszczeń akurat w tamtym okresie mogło być odbierane jako współdziałanie z Rosją przy osłabianiu Ukrainy. Jednak Węgry, mimo pewnych złośliwych uwag pod adresem Kijowa, na forum ONZ deklarowały poparcie dla jej integralności terytorialnej. Minister Szijarto postulował także wsparcie transformacyjne dla tego kraju. Październik 2017 r. przyniósł kryzys wokół ukraińskiej ustawy oświatowej. Eskalacja konfliktu była bardzo duża, a węgierscy nacjonaliści z partii Jobbik wzywali wręcz do militarnego ataku na Ukrainę. Rząd Węgier zapowiedział negowanie korzystnych dla Kijowa decyzji na forum UE. I mimo że obecnie (czerwiec 2017 r.) łagodzi nieco stanowisko, obawy o przyszłość relacji węgiersko-ukraińskich są bardzo zasadne.

33 https://dailynewshungary.com/orban-putin-meeting-budapest/ (dostęp: 15 października 2017).

34 A. Sadecki, Państwo stanu wyższej konieczności. Jak Orban zmienił Wegry, https://www.osw.waw. pl/sites/default/files/pw_41_panstwo-stanu-wyzszej-koniecznosci_net.pdf (dostęp: 15 czerwca 2015).

${ }^{35}$ New era to begin in Hungarian-Iran relations, http://www.kormany.hu/en/the-prime-minister/ news/new-era-about-to-begin-in-hungarian-iranian-relations (dostęp: 16 października 2017).

36 W chwili gdy powstaje niniejszy artykuł (październik 2017), sytuacja ponownie zaostrza się po uchwaleniu przez Ukrainę kontrowersyjnej ustawy językowej. Orban i Szijarto grożą, że jeśli Ukraina nie zmieni dyskusyjnych zapisów, Węgry będą blokować wszystkie korzystne dla Ukrainy umowy z UE. 
Orban — w młodości zwolennik myślenia o polityce zagranicznej bardziej w duchu neokonserwatyzmu - postuluje obecnie przebudowę ładu międzynarodowego. Jednak paradygmat realistyczny, na który powołuje się rząd Węgier, interpretowany jest przy uwzględnieniu ograniczeń, jakie są udziałem małego kraju, takiego jak Węgry. Rząd Fideszu nigdy nie podważył idei integracji. Co więcej, dostrzega w UE narzędzie zabezpieczenia węgierskich interesów ${ }^{37}$. Jednocześnie jednak Węgry czekają na moment, w którym mogłoby dojść do radykalnego zwiększenia ich roli we Wspólnocie. A takie nadzieje pokładane są w Budapeszcie w nowym rozdaniu w polityce europejskiej i udziałach w rządach takich sił, jak Front Narodowy, partia Gerda Wildersa, CSU Horsta Seehofera czy Alternatywa dla Niemiec. W takim rozdaniu zjednoczona Europa wciąż łagodziłaby pewnie napięcia w relacjach $\mathrm{z}$ Rosją. Z punktu widzenia polskiego rządu należy postawić pytanie: jak w takiej Europie wyglądałaby pozycja nie tylko Ukrainy, lecz także Polski?

Węgry starają się odgrywać rolę państwa, które oferuje Chinom najlepsze warunki inwestycyjne w tej części Europy. Chodzi o warunki zarówno ekonomiczne, jak i polityczne. Węgry nie tylko nie pytają o prawa człowieka, ale też sam Orban — np. w Baile Tusnad - nie ukrywał fascynacji chińskim modelem państwa. Węgierskie podejście owocuje konkretnymi inwestycjami. Eksperci pisma „Forbes” zwracają uwagę na niekorzystny dla Polski bilans relacji gospodarczych z Chinami (po 2016 r.) w stosunku do analogicznego bilansu Węgier ${ }^{38}$. Sztandarową inwestycją na Węgrzech jest oczywiście wspomniana linia Budapeszt-Belgrad. Z punktu widzenia interesów regionu obawy może budzić węgierskie poparcie dla przebudowy systemu międzynarodowego w kierunku zwiększenia roli Rosji i Chin.

\section{Polska}

Omówienie polskiej polityki zagranicznej w kontekście V4 to bez wątpienia temat na osobny artykuł. Dlatego zasygnalizujemy tylko najważniejsze problemy związane z tym zagadnieniem.

Dla polskiego czytelnika oczywistością będzie stwierdzenie, że polska polityka zagraniczna przeszła w ostatnich dwóch latach najbardziej istotne przemiany. Wydaje się jednak, że dotyczą one przede wszystkim pozycji Polski w UE. Rząd Platformy Obywatelskiej widział miejsce Polski wśród państw odgrywających znaczną rolę w polityce europejskiej. Pewnym uproszczeniem byłoby stwierdzenie, iż polityczna wizja Donalda Tuska opierała się na „trzymaniu twardego jądra”. Pol-

37 Orban, wiem, co należy do moich obowiązków i co muszę wykonać, z Viktorem Orbanem rozmawia Zsolt Bayer, http://www.fronda.pl/a/orban-wiem-co-nalezy-do-moich-obowiazkow-i-co-musze-wykonac,29680.html (dostęp: 3 maja 2015).

38 D. Hutt, China's relationship with Hungary is being tested as the EU and Russia apply pressure, https://www.forbes.com/sites/davidhutt/2017/09/05/chinas-relationship-with-hungary-is-hitting-arocky-patch/ (dostęp: 5 grudnia 2017). 
ska miała być, powiedzmy nieco przewrotnie, „unijnym silnym graczem średniej wielkości”. Jako że nasz kraj nie może być (i obecny rząd także ma tę świadomość) podmiotem polityki europejskiej o potencjale Niemiec i Francji, z założenia mieliśmy odgrywać rolę podobną do państw porównywalnych z Polską wielkością i potencjałem, takich jak Włochy czy Hiszpania. Takie założenia formułowali zresztą wcześniej doradcy Lecha Kaczyńskiego.

Należy jednak zwrócić uwagę, że wspomniana idea Trójmorza jest pewną kontynuacją w polskiej polityce zagranicznej. Cała inicjatywa nabierała konkretnych kształtów już w okresie premierostwa Donalda Tuska ${ }^{39}$. Choć w tamtym okresie sama idea była jeszcze w fazie dyskusji, mówiło się o stworzeniu Grupy ABC na bazie CEFTA. W koncepcji politycznej Platformy Polska miała nie tyle być liderem Europy Środkowej, ile raczej Europa Środkowa miała stać się narzędziem osiągania polskich celów w UE. Poprzedni rząd potrafił budować regionalne koalicje w ramach UE. Cały projekt Trójmorza konkretniejszy kształt przybrał jednak dopiero latem 2015 r. z inicjatywy nowego polskiego prezydenta Andrzeja Dudy oraz prezydent Chorwacji Kolindy Grabar-Kitarović. Początkowo polska dyplomacja dążyła do stworzenia szerszej geopolitycznej Unii krajów regionu, czyli wspomnianego Międzymorza. Inicjatywa ta zderzyła się jednak z przeszkodami leżącymi w wizjach polityki zagranicznej w innych krajach regionu ${ }^{40}$. Międzymorze miało być mocno osadzone w ramach UE. Poprzez stworzenie bloku państw regionu o podobnym doświadczeniu historycznym zamierzano osiągnąć dwa cele: wzmocnić wschodnią, chroniąca przed Rosją flankę Wspólnoty oraz stworzyć przeciwwagę dla wpływów Niemiec tam, gdzie interesy Berlina - sztandarowy przykład to oczywiście Nord Stream 2 - nie pokrywają się z interesami regionu. Szybko jednak okazało się, że niektóre kraje regionu, jak np. Serbia czy Bułgaria, są z natury przeciwne wszelkim inicjatywom, które mogą być postrzegane jako antyrosyjskie $^{41}$. Inne - ten czynnik dotyczy przede wszystkim pozostałych państw Grupy Wyszehradzkiej - wiążą swoją przyszłość z sojuszem geopolitycznym z Niemcami. Wynika to przede wszystkim ze ścisłych powiązań gospodarczych całego regionu $\mathrm{z}$ gospodarką niemiecką. Poza tym polskim władzom nie udało się uniknąć wrażenia, że Międzymorze mogłoby stać się niejako alternatywą dla integracji europejskiej. Niestety dla niemal żadnego z krajów regionu taka alternatywa nie mogła być atrakcyjna. Na takie postrzeganie polskiej inicjatywy wpłynął

39 To właśnie wtedy podjęto próby tworzenia Grupy ABC (Adriatyk, Bałtyk, Morze Czarne). Jej inicjatorami były także Polska i Chorwacja.

40 Poza Chorwacją i warunkowo Rumunią pomysł Międzymorza wszędzie był niezauważany lub krytykowany. Niektóre państwa, jak np. Słowacja czy Czechy, obawiały się, że polski projekt ma być pewną „kontrą” wobec UE. Reakcja Węgier była dość przychylna, jednak między wierszami wypowiedzi węgierskich mediów i polityków można było wyczytać, że Węgrzy marzą o własnym projekcie regionalnym.

41 Kraje te wierzą w możliwość pogodzenia członkostwa w UE z dobrymi relacjami z Rosją. 
przede wszystkim spór o praworządność w Polsce, który w tym momencie jest ogromnym balastem dla polskiej polityki europejskiej, lecz także regionalnej.

W pierwszym okresie rządów Prawa i Sprawiedliwości (2005-2007) celem polskiej polityki zagranicznej było zwiększenie podmiotowości kraju w polityce europejskiej. Nawet niektórzy analitycy nieprzyjaźni poprzedniemu rządowi przyznają, że pewne sukcesy - np. w czasie obrony Traktatu w Nicei - zostały osiągnięte ${ }^{42}$. Wydaje się, że gdy w 2015 r. PiS wracał do władzy, celem była także asertywna, ale wciąż ściśle osadzona w unijnym kontekście, polityka zagraniczna Polski. Jednak bez względu na to, jak z naszego polskiego punktu widzenia oceniamy spór o Trybunał Konstytucyjny, o sądownictwo, kolejne groźby sankcji oraz brak postępu w negocjacjach niezwykle negatywnie wpływają na naszą pozycję w UE. Dochodzi do sytuacji, w której Polska nie jest zdolna do doraźnych sukcesów, nawet jeśli racja wydaje się ewidentnie leżeć po naszej stronie. Przykładem jest choćby spór o pracowników delegowanych ${ }^{43}$. Tymczasem, może poza Węgrami, wszystkie kraje V4 i szerzej pojętego Międzymorza widzą swoją przyszłość w integracji, a często - jak to ma miejsce w wypadku państw bałtyckich lub Rumunii - rządy te zabiegają o pozycję $\mathrm{w}$ twardym jądrze. I niestety obecnie ciężko naszym władzom przeforsować projekt nie tylko Międzymorza, lecz także znacznie bardzie realny i dobrze widziany $\mathrm{w}$ regionie projekt Trójmorza. Trzeba w tym miejscu podkreślić, że Trójmorze tym różni się od Międzymorza, że nie zakłada trwałej wspólnoty geopolitycznej, a właśnie koalicję w ramach UE i współpracę w celu przyspieszenia modernizacji ${ }^{44}$. Nierozwiązanie problemu $w$ relacjach $z$ UE może jednak rzutować również na nasze relacja w ramach Grupy Wyszehradzkiej. Ostatnimi czasy dość silne są głosy w Czechach i na Słowacji, że utożsamianie ich z oskarżanymi o autorytaryzm rządami Polski i Węgier negatywnie wpływa na wizerunek Pragi i Bratysławy w UE ${ }^{45}$.

Zdaniem nie tylko polskich analityków Polskę od innych krajów Grupy Wyszehradzkiej odróżnia zdecydowany sprzeciw wobec polityki Władimira Putina. Faktycznie, w ciągu pierwszych dwóch lat rządów Prawa i Sprawiedliwości nie można

42 Polityka zagraniczna Lecha Kaczyńskiego post factum jest przez tzw. liberalne media oceniana zdecydowanie lepiej niż w latach 2005-2007. Być może dlatego, że wydaje się, iż przy pewnych zasadniczych rozbieżnościach, jak np. relacje Polska-, „warde jądro”, istniał też między PO i PiS pewien konsensus, m.in. w sprawie wsparcia dla Ukrainy. Co więcej, gdy ministrem był Radosław Sikorski, który sugerował powrót do „piastowskiej wizji polityki zagranicznej”, PiS występował w obronie linii prometejskiej. Sympatie obozu proukraińskiego zdawały się wówczas przechylać na korzyść PiS, a minister Sikorski musiał odejść od niektórych swoich tez o linii piastowskiej, stwierdzając, że „o Giedroycia sporu nie ma”- http://www.new.org.pl/4526-o-giedroycia-sporu-nie-ma (dostęp: 1 grudnia 2017).

43 http://tvn24bis.pl/z-kraju,74/pracownicy-delegowani-panstwa-ue-uzgodnily-stanowisko,783993.html (dostęp: 1 grudnia 2017).

44 https://www.tvn24.pl/magazyn-tvn24/wielki-plan-malych-panstw-jak-trojmorze-wzmocni -lub-podzieli-unie,106,1968 (dostęp: 1 grudnia 2017).

45 Takie głosy były w Czechach i na Słowacji wręcz powszechne w czasie polskiego kryzysu sądowego w lipcu 2017 r. 
raczej mówić o pojednawczych gestach polskiego rządu pod adresem Moskwy. Tym niemniej, istnieje w obrębie prawicy pewien nurt, który dostrzega możliwość polsko-rosyjskiego sojuszu na gruncie konserwatyzmu i sprzeciwu wobec europejskiego modelu liberalizmu ${ }^{46}$. Oczywiście należy pamiętać o wielu analizach wskazujących na fikcyjność rosyjskiego zwrotu w kierunku obyczajowego konserwatyzmu i koniunkturalność wykorzystywania przez Moskwę tego typu nastrojów ${ }^{47}$. W tym momencie dość jasne jest, że sprawa tragedii smoleńskiej wyklucza geopolityczny zwrot Polski. Inna kwestia to to, że mimo doraźnie używanej retoryki antyunijnej i antyniemieckiej wydaje się, że obecne władze widzą Polskę jako członka świata euroatlantyckiego ${ }^{48}$. Dlatego w polskich mediach coraz głośniej mówi się o tym, iż nie mając nadziei na prorosyjski zwrot Polski, taktyka Rosji polega na „wbijaniu klina” między Polskę i Ukrainę ${ }^{49}$. W wypadku coraz poważniejszych napięć między oboma państwami naprawdę trudno odróżnić, kiedy mamy do czynienia z działaniami inspirowanymi Rosją, a kiedy ujawniają się po prostu ukryte wcześniej animozje między elitami obu państw ${ }^{50}$. Faktem jest, że w pierwszym okresie po ukraińskiej rewolucji godności postawa Platformy Obywatelskiej była przyjazna Ukrainie, ale ogólnie dość wstrzemięźliwa. Wówczas Prawo i Sprawiedliwość, kontynuując prometejską politykę Lecha Kaczyńskiego, optowało za silniejszym wsparciem dla pomajdanowych władz Ukrainy. Zmianę retoryki dało się dostrzec w 2015 r. Obecny minister w kancelarii prezydenta, Krzysztof Szczerski, mówił wówczas, że celem polskiej dyplomacji zawsze było „umiędzynarodowienie problemu Ukrainy”. Po Majdanie, gdy cel ten został osiągnięty, Polska, nadal wspierając Kijów w europejskich aspiracjach, „może być nieco bardziej asertywna"51. Ta asertywność miała się przejawiać w podnoszeniu trudnych dla Polski kwestii historycznych. Niestety, uchwała polskiego Sejmu w sprawie Wołynia, która zawierała także pojednawcze elementy, wywołała reakcję łańcuchową na Ukrainie ${ }^{52}$. Wydaje się, że w sedno problemu trafił ukraiński historyk Jarosław Hrycak, zdaniem którego przez długie lata Polska wykazywała się pojednawczością wobec Ukrainy i uznawała, iż przebiegający tam proces formowania narodu „wymaga większej wyrozumiałości”. Po Majdanie Jarosław Kaczyński miał uznać, że Ukraińcy pokazali, że są dojrzałym narodem, dlatego

46 Nurt ten jest jednak w Polsce relatywnie słabszy niż np. na Węgrzech.

47 J. Schwertner, PiS przeorze system, spór zepsuje, ale my tego potrzebujemy, wywiad z Witoldem Juraszem, http://wiadomosci.onet.pl/tylko-w-onecie/jurasz-pis-przeorze-system-sporo-zepsuje-ale -my-tego-wstrzasu-potrzebujemy-wywiad/wd19yqr (dostęp: 3 grudnia 2017).

48 Ibidem.

49 Ibidem.

50 Teza ta pojawia się zarówno w polskich, jak i ukraińskich debatach.

51 Minister przedstawiał taką wizję w swoich wystąpieniach jeszcze wiosną 2015 r., przed objęciem urzędu.

52 Pojawiło się wiele nieprzyjaznych Polsce komentarzy, niektórzy ukraińscy dziennikarze uczynili wręcz konflikt polsko-ukraiński głównym tematem swej publicystyki (a także aktywności w mediach społecznościowych). 
można podnieść pewne odłożone do tej pory na bok kwestie historyczne. Jednocześnie zdaniem Hrycaka Jarosław Kaczyński uważa, że Ukraina buduje swoją nową tożsamość wokół kultu Stepana Bandery. Kaczyński, jak wiemy, powiedział „Z Banderą Ukraina do Unii nie wejdzie. Ukraina musi wybrać - albo Bandera i Wschód, albo inni bohaterowie i Zachód"53. Wypowiedź ta była niezwykle szeroko i negatywnie komentowana przez ukraińskie media. Dla części zajmujących się relacjami z Polską ukraińskich intelektualistów, jak np. wspomniany Hrycak czy Jurij Andruchowycz, polska narracja dotycząca Bandery jest mało zrozumiała ${ }^{54}$. Zdaniem wielu Ukraińców „kult Bandery” jest ograniczony do Galicji i w skali Ukrainy ma charakter marginalny ${ }^{55}$. Trzeba jednak uczciwie powiedzieć, że ukraińska strona, w tym wielu ukraińskich publicystów, wykorzystała działania PiS do sięgnięcia po dość mocno nieprzychylną Polsce retorykę. Pozostaje zatem pytanie, czy uda się ostudzić nastroje po obu stronach i przywrócić właściwy kształt polsko-ukraińskiego dialogu.

W relacjach z Chinami obserwujemy wyraźnie mniejszy entuzjazm Polski do koncepcji „Nowego Jedwabnego Szlaku”. Polskie relacje z Chinami nigdy nie były tak problematyczne, jak np. czeskie, choć oczywiście kwestii spornych nie brakowało. Należy przypomnieć, że w 2008 r. zarówno ówczesny premier Donald Tusk, jak i prezydent Lech Kaczyński nie uczestniczyli w otwarciu olimpiady w Pekinie. Gest ten, ciepło przyjęty przez obrońców praw człowieka, spotkał się z negatywną oceną strony chińskiej ${ }^{56}$. Inna sytuacja związana jest $z$ pierwszym szczytem w formacie $16+1$, który odbył się w Warszawie w 2012 r. Znana jest wypowiedź prezydenta Komorowskiego, który zapytany o stanowisko w kwestii praw człowieka w Chinach, powiedział wówczas „bardzo ważne, bardzo ważne, bardzo ważne" 57 . Jednakże, porównując wypowiedzi zarówno polityków, jak i ośrodków analitycznych, wydaje się, że Polska nieco mniej entuzjastycznie podchodzi do „otwarcia na Chiny”. O ile czescy, słowaccy czy węgierscy analitycy przyjmują jako pewnik „wyłącznie ekonomiczny charakter współpracy $16+1$ ”, o tyle w Polsce pojawia się więcej wątpliwości, które dotyczą potencjalnej przyszłej ekspansji politycznej „państwa środka”. Tym niemniej, także w Polsce z chińską obecnością w regionie wiązane są nadzieje, np. na realizację infrastrukturalnych i energetycznych projektów w ramach Trójmorza.

53 J. Hrycak, Ukrainsko-polskogo konflikty nemaje, https://zbruc.eu/node/72947 (dostęp: 25 listopada 2017).

54 Ibidem.

55 Ciężko zweryfikować tę tezę, faktem jest natomiast duża popularność Bandery wśród młodych Ukraińców. Należy jednak przyznać rację tym ukraińskim historykom i publicystom, którzy twierdzą, że popularność ta jak na razie oparta jest przede wszystkim na postrzeganiu Bandery jako bohatera walki z Rosją.

56 S. Niewiński, Gtuchy telefon. Stosunki polsko-chińskie, http://www.geopolityka.org/analizy/stanislaw-niewinski-gluchy-telefon-stosunki-polsko-chinskie (dostęp: 1 grudnia 2017).

57 Ta wypowiedź została uznana za pewne umiarkowane desinteressment polskiego rządu w kwestii praw człowieka w Chinach. 


\section{Podsumowanie}

Eksperci Ośrodka Studiów Wschodnich w pracy na temat postawy państw Grupy Wyszehradzkiej wobec kryzysu ukraińskiego zwracają uwagę, że choć Czechy, Słowacja i Węgry unikają zajęcia jednoznacznego stanowiska w ocenie politycznej konfliktu, wszystkie te kraje „na nowo odkrywają Ukrainę” zarówno jako partnera gospodarczego, jak i jako rodzącą się europejską demokrację. Notujemy obecnie najwyższe nasilenie wymiany handlowej i kulturowej między tymi krajami a Ukrainą. Trzeba pamiętać, że Ukraina, stojąca wobec wyzwania, jakim jest przeprowadzenie realnej transformacji, takiego wsparcia potrzebuje może nawet bardziej niż wsparcia geopolitycznego.

$\mathrm{Na}$ początku artykułu odnotowaliśmy brak wspólnej agendy państw V4 po 2004 r. W 2014 r. wydawało się, że niemożliwość wypracowania wspólnej agendy między jednoznacznie popierającą Ukrainę Polską a wstrzemięźliwymi Czechami, Słowacją i Ukraina grozi wręcz rozbiciem V4. Gdy jednak stało się jasne, że Rosja dąży do trwałej przebudowy przestrzeni postkomunistycznej, w Budapeszcie, Pradze i Bratysławie powoli dojrzewała świadomość, że nie można układać się z Rosją za cenę ryzyka regionalnego konfliktu. Obecnie, mimo że wszystkie trzy analizowane państwa utrzymują poprawne (zważywszy na obecne realia) relacje z Rosją, każdy z rządów bardzo mocno optuje za integralnością terytorialną Ukrainy. Wydaje się, że większy problem leży po stronie Warszawy. W samym Prawie i Sprawiedliwości coraz większego znaczenia zdaje się nabierać nurt określany przez prometeistę Pawła Kowala mianem neoendeckiego. Mimo że głosy na rzecz resetu z Rosją są w PiS marginalne i pojawiają się raczej tylko w środowiskach związanych z Radiem Maryja. Istnieje więc ryzyko, że Polska znajdzie się „dalej od Kijowa” niż pozostałe państwa V4. Jednak jako że politycy PiS wykonują również przyjazne gesty pod adresem Ukrainy, wobec wspomnianych korzystnych przemian $\mathrm{w}$ pozostałych państwach można mieć nadzieje, że idea korzystnego dla Europy Środkowej ułożenia przestrzeni państw między naszymi granicami a Rosją stanie się jednym z czynników spajających V4. Jeśli uwzględnimy konieczność utrzymania relacji gospodarczych z Rosją, to zachowanie integralności terytorialnej Ukrainy oraz stabilizacja krajów Partnerstwa Wschodniego może być płaszczyzną łączącą Polskę, Czechy i Słowację. Akurat bowiem w kwestii Ukrainy władzom Węgier zdaje się brakować minimum dobrej woli. $\mathrm{W}$ połączeniu $\mathrm{z}$ wspólnymi interesami $\mathrm{w}$ polityce europejskiej, które z pewnością pojawią się w przyszłości, można spodziewać się restytucji współpracy wyszehradzkiej i być może tworzenia szerszych koalicji regionalnych. Choć oczywiście pytanie, na ile realne są polskie pomysły bloku regionalnego (tzw. Trójmorza), pozostaje otwarte.

Pomimo widocznej wspólnoty interesów mają miejsce także rozbieżności choćby w kwestii Rosji, w wypadku której kraje szerzej pojętego regionu Europy Środkowej postrzegają to mocarstwo bądź jako tradycyjnego sojusznika (np. Ser- 
bia czy Bułgaria), bądź nie widzą w rosyjskiej ekspansji zagrożenia dla własnej niepodległości (np. Słowacja czy Węgry). Występują także inne rozbieżności interesów, np. kraje będące członkami Strefy Euro, jak choćby Słowacja, zdecydowanie opowiadają się za przyspieszeniem integracji. Trzeba pamiętać, że $-\mathrm{z}$ wyjątkiem Czech i może Węgier - wszystkie kraje regionu wypracowały raczej konsensus co do konieczności dalszej integracji europejskiej. Z tego też powodu państwa te bardzo niechętnie patrzą na polski spór z Komisją Europejską.

Na koniec należy odnieść się do instrumentów wpływu w regionie, jakimi dysponują Rosja i Chiny. Mniej więcej do 2012 r. mogliśmy obserwować dość jednoznaczny euroatlantycki kurs krajów Wyszehradu. Obecnie jednak Moskwa i Pekin skutecznie budują swoje wpływy w regionie. Poza Polską żaden z krajów Wyszehradu nie zakłada raczej realnej groźby agresji rosyjskiej w ciągu najbliższych pięciu lat. Dlatego trudno o tezę, by za „otwarciem na Rosję" tamtejszych elit stała konieczność zapobiegnięcia inwazji poprzez détente. Tak naprawdę Rosja i Chiny bardzo umiejętnie budują swoją soft power w regionie (na użytek tego artykułu należy przyjąć klasyczną definicję soft power jako zdolności danego kraju do pozyskiwania sojuszników za pomocą budowy jego atrakcyjnego obrazu w innym państwie).

W krajach Wyszehradu odchodzą powoli ze sceny politycznej idealistyczne elity lat 90., zastępowane przez pragmatyków czy też - zdaniem niektórych pozornych pragmatyków. Już w poprzedniej dekadzie w potocznym dyskursie w naszym regionie można było usłyszeć opinie typu „nie podoba mi się polityczny system Rosji i Chin, ale przecież możemy z tymi państwami handlować”. Oba kraje bardzo umiejętnie kreują wizję korzyści, jakie może przynieść wymiana handlowa. „Nowy Jedwabny Szlak” i „Projekt $16+1$ ” to chińskie pomysły, które wręcz fascynują środkowoeuropejskie stolice ${ }^{58}$. Pekin wykorzystuje dążenia rządów w regionie do „przyspieszonej modernizacji”, pokazując możliwości takiej modernizacji przy wykorzystaniu chińskich inwestycji. Musimy jednak pamiętać o szczycie formatu $16+1$ w listopadzie 2016 r. Stało się wówczas aż nadto jasne, że Pekin „nagradza” kraje niepodnoszące kwestii praw człowieka oraz „karze” te, które próbują o tych kwestiach rozmawiać. Eksperci OSW podają tu przykład „dobrej” Łotwy i „złej” Estonii ${ }^{59}$. Rosja natomiast kusi korzyściami gospodarczymi przede wszystkim w sferze energetyki. Moskwa buduje jednak także branding alternatywnej cywilizacji, bardziej (rzekomo) atrakcyjnej niż Zachód. Trzeba pamiętać, że taki obraz Rosji był atrakcyjny w Czechach i na Słowacji od czasów wspomnianego

58 Por. np. Agenda pro ceskou zahranicni politiku 2016, https://www.amo.cz/wp-content/uploads/2016/04/AMO-Agenda-pro-\%C4\%8Deskou-zahrani\%C4\%8Dn\%C3\%AD-politiku-2016.pdf (dostęp: 17 sierpnia 2017).

59 M. Kaczmarski, J. Jakubowski, J. Hyndle-Hussein, Szczyt Chiny-Europa Środkowa: nowa wizja wspólpracy, stare instrumenty, https://www.osw.waw.pl/pl/publikacje/analizy/2015-12-02/szczytchiny-europa-srodkowo-wschodnia-nowa-wizja-wspolpracy-stare- (dostęp: 5 grudnia 2017). 
Karla Havliczka (na Słowacji - Ludwika Stura ${ }^{60}$ ). Obecnie jednak również w historycznie skonfliktowanej z Rosją Polsce oraz na Węgrzech odwoływanie się przez Moskwę do idei „obrony chrześcijaństwa” zaczyna budzić coraz większą sympatię w kręgach tzw. prawicy. Sygnały te są w rosyjskiej stolicy dostrzegane, o czym świadczy np. wiara w przeformowanie ideologii Aleksandra Dugina w kierunku uznania Polski za wartościową cywilizację słowiańską z prawem do niepodległości w przyszłym „rosyjskim świecie” 61 .

Wystąpienie Orbana w Baile Tusnad to najlepszy przykład siły rosyjskiej soft power $\mathrm{w}$ regionie ${ }^{62}$. Z kolei chińskie wpływy kulturowe w regionie są bardziej subtelne, ale działalność fundacji, takich jak np. Instytut Konfucjusza, buduje pewną grupę elit zafascynowanych cywilizacją chińską nie tylko w krajach V4, lecz także w Europie Zachodniej. Musimy jednak pamiętać o pewnej konkurencji między projektami „Nowego Jedwabnego Szlaku” a Unii Euroazjatyckiej ${ }^{63}$.

Widzimy zatem, że mimo zasadniczo dobrych perspektyw współpracy regionalnej równie wielkim zagrożeniem, jak infiltracja regionu przez Rosję i Chiny, wydaje się dobrowolne ulegnięcie tamtejszym wpływom przez miejscowe elity.

\section{Bibliografia}

\section{Literatura}

Agenda pro cesku zahranicni politiku 2014, https://www.amo.cz/cs/agenda-pro-ceskou-zahranicni -politiku/agenda-pro-ceskou-zahranicni-politiku-2014/.

Agenda pro cesku zahranicni politku 2015, https://www.amo.cz/cs/agenda-pro-ceskou-zahranicni -politiku/agenda-pro-ceskou-zahranicni-politiku-2015/.

Agenda pro cesku zahranicni politiku 2016, https://www.amo.cz/cs/agenda-pro-ceskou-zahranicni -politiku/agenda-pro-ceskou-zahranicni-politiku-2016/.

Bajda P., Elity polityczne na Słowacji w latach 1989-2010. Kręta droga do nowoczesnego państwa, Warszawa 2010.

Co może cinskych turistu prilakat na Slovensko? Cisty vzduch a nakupy?, https://cestovanie.pravda. sk/cestovny-ruch/clanok/353318-co-moze-cinskych-turistov-prilakat-na-slovensko-cisty-vzduch-aj-nakupy/.

Ctyri najvyssi politici se distancovali od schuzki Hermana z Dalajlamou, http://zpravy.idnes.cz/ctyri-nejvyssi-politici-se-distancovali-od-schuzky-hermana-s-dalajlamou-14q-/domaci.aspx?c= A161018_160816_domaci_kop.

Cuprik R., Fico, potrebujem aby se Kiska koncentroval, https://domov.sme.sk/c/20672305/fico-z-odmeny-pre-bzana-by-sme-sa-mali-poucit.html?ref=njctse.

Drulak konci na zahranici. Nepohodl se s ministrem, https://www.novinky.cz/domaci/408644-drulak -konci-na-zahranici-nepohodl-se-s-ministrem.html.

60 Stur to „ojciec” słowackiego odrodzenia narodowego.

61 Globalizm i liberalizm to cywilizacja Antychrysta, z Aleksandrem Duginem rozmawia Maciej Pieczyński, https://dorzeczy.pl/kraj/18103/Globalizm-i-liberalizm-to-cywilizacja-Antychrysta.html. (dostęp: 2 grudnia 2017).

62 Orban w Baile Tusnad stawiał Rosję za wzór „sprawnej, nieliberalnej demokracji”.

63 M. Lubina, Niedźwiedź w cieniu smoka. Rosja-Chiny 1991-2004, Kraków 2014. s. 390-396. 
Drulak P., Lidska prava v zahranicni politice anem sneni k naivite. A zpet?, http://denikreferendum.cz/ clanek/17205-lidska-prava-v-zahranicni-politice-aneb-od-sneni-k-naivite-a-zpet.

Drulak P., Tri rozmery ceske debaty o zahranicni politice lidskych prav, [w:] Lidská práva: (ne)smysl české politiky?, red. J. Přibáň, V. Bělohradský, Praha 2015.

Fico se ma na sumitu $v$ Rize ptat $i$ na lidska prava $v$ Cine, https://www.denik.cz/ze_sveta/fico-se-ma -na-summitu-v-rize-ptat-i-na-lidska-prava-v-cine-20161103.html.

Furst R., Cesko-cinske vztachy, od bezradnosti k aktivni politce, UMV policy papers, http://www.iir.cz/ en/article/cesko-cinske-vztahy-od-bezradnosti-k-aktivni-politice.

Globalizm i liberalizm to cywilizacja Antychrysta, z Aleksandrem Duginem rozmawia Maciej Pieczyński, https://dorzeczy.pl/kraj/18103/Globalizm-i-liberalizm-to-cywilizacja-Antychrysta.html

Groszkowski J., Iwański T., Sadecki A., Raport OSW: Sąsiad odkrywany na nowo. Stosunki Czech, Stowacji $i$ Wegier $z$ Ukraina, https://www.osw.waw.pl/pl/publikacje/raport-osw/2017-08-03/sasiad-odkrywany-na-nowo-stosunki-czech-slowacji-i-wegier-z-ukraina.

Hrycak J., Ukrainsko-polskogo konflikty nemaje, https://zbruc.eu/node/72947.

Hutt D., China's relationship with Hungary is being tested as the EU and Russia apply pressure, https:// www.forbes.com/sites/davidhutt/2017/09/05/chinas-relationship-with-hungary-is-hitting-arocky-patch/.

Kaczmarski M., Jakubowski J., Hyndle-Hussein J., Szczyt Chiny-Europa Środkowa: nowa wizja wspótpracy, stare instrumenty, https://www.osw.waw.pl/pl/publikacje/analizy/2015-12-02/szczyt-chiny -europa-srodkowo-wschodnia-nowa-wizja-wspolpracy-stare-.

Lubina M., Niedźwiedź w cieniu smoka. Rosja-Chiny 1991-2004, Kraków 2014.

Nejedly T., Cina sype do Evropy miliardy Slovensko nevidi, https://www.etrend.sk/trend-archiv/rok2015/cislo-39/cinske-miliardy-obchadzaju-slovensko.html.

New era to begin in Hungarian-Iran relations, http://www.kormany.hu/en/the-prime-minister/news/ new-era-about-to-begin-in-hungarian-iranian-relations.

Niewiński S., Głuchy telefon. Stosunki polsko-chińskie, http://www.geopolityka.org/analizy/stanislawniewinski-gluchy-telefon-stosunki-polsko-chinskie.

Ondercanin L., Vasaryova, ked sa Polsko a Madarsko dohaduji bez nas musime byt opatrni, https:// www.sme.sk/diskusie/3182096/4/Vasaryova-Ked-sa-Polsko-a-Madarsko-dohaduju-bez-nasmusime-byt-opatrni.html.

Orban V., Baile Tusnad speech, https://budapestbeacon.com/full-text-of-viktor-orbans-speech-at-bailetusnad-tusnadfurdo-of-26-july-2014/.

Orban, wiem, co należy do moich obowiązków i co muszę wykonać, z Viktorem Orbanem rozmawia Zsolt Bayer, http://www.fronda.pl/a/orban-wiem-co-nalezy-do-moich-obowiazkow-i-co-musze -wykonac,29680.html.

Pruzkum: Cesi duveruji najvice papezovi a Zemanovi. Merkelova se propada, https://www.lidovky.cz/ pruzkum-cesi-duveruji-nejvice-papezovi-a-zemanovi-merkelova-se-propada-1af-/zpravy-domov.aspx?c=A160127_170913_ln_domov_ELE.

Sadecki A., Państwo stanu wyższej konieczności. Jak Orban zmienił Węgry, https://www.osw.waw.pl/ sites/default/files/pw_41_panstwo-stanu-wyzszej-koniecznosci_net.pdf.

Schwertner J., PiS przeorze system, spór zepsuje, ale my tego wstrząsu potrzebujemy, wywiad z Witoldem Juraszem, http://wiadomosci.onet.pl/tylko-w-onecie/jurasz-pis-przeorze-system-sporo-zepsuje-ale-my-tego-wstrzasu-potrzebujemy-wywiad/wd19yqr.

Slovensko se stava poslusnym clenem EU. Fico se pry ohledne bezencu s Junckerem placl, http://www. parlamentnilisty.cz/arena/monitor/Slovensko-se-stava-poslusnym-clenem-EU-Fico-si-pry -ohledne-bezencu-s-Junckerem-placl-498119.

To by bylo, aby se na vás něco nenašlo, rozmowa Petra Holuba z Miroslavem Kalouskiem, „Týdeník Echo" 12.10.2017, nr 41, https://echo24.cz/a/p7cWA/to-by-bylo-aby-se-na-vas-neco-nenaslo.

Tramba D., Ruske investice v Cesku rosnou. Mnohe ale krahuji, http://www.dotyk.cz/publicistika/ruske-investice-v-cesku-rostou-mnohe-ale-krachuji-20160811.html. 
V. Orban o wyborach w USA. To koniec epoki liberalnej niedemokracji, https://wpolityce.pl/polityka/ 314950-viktor-orban-jednoznacznie-o-wyborach-w-usa-to-koniec-epoki-liberalnej-niedemokracji.

Zeman stratil svym chovanim $v$ CSSD behem vladni krize vliv, rika sef Sobotkovych poradcu Spidla, https://archiv.ihned.cz/c1-65741920-zeman-ztratil-svym-chovanim-behem-vladni-krize-v-cssd-vliv -rika-sef-sobotkovych-poradcu-spidla.

Zeman vztach $k$ Rusko je ambivalentni. NATO ho kritizuje i bere za partnera, https://www.lidovky.cz/ zeman-vztah-k-rusku-je-ambivalentni-nato-ho-kritizuje-i-bere-za-partnera-1au-/zpravy-domov.aspx?c=A160709_190434_ln_domov_ele.

\section{Strony internetowe}

http://www.denikreferendum.cz/rubrika/vikend.

http://www.fronda.pl/.

http://www.hungarianspectrum.org/category/hungarian-politics-2/.

http://www.tvn24bis.pl.

https://www.dailynewshungary.com/.

https://www.dotyk.cz/.

https://www.echo24.cz/.

https://www.ihned.cz/.

https://www.lidovky.cz/.

https://www.onet.pl/.

https://www.pravda.sk/.

https://www.sme.sk/.

https://www.wpolityce.pl/. 